\title{
Being Dead in Shakespearean Tragedy
}

\author{
Mary Ann Lund
}

In his novel Being Dead (1999), Jim Crace intertwines the life of a married couple, both zoologists, with an account of what happens after their deaths. We learn at the beginning of the novel that they have been murdered on a beach, and their bodies lie undiscovered for some time. Their physical decomposition is described in details that are simultaneously scientific and loving. The unfurling of this story is prefaced by an epigraphic verse, "The Biologist's Valediction to his Wife" (purportedly by Sherwin Stephens, a pseudonym for Crace), which provides a quite different perspective on being dead. Where the novel is tender, the poem is comically stark. The speaker of the poem declares to his wife that there is no chance of eternal life: "You're dead. That's it. Adieu. Farewell". Death is an entirely one-way process of "Rot, Rot, Rot,/As you regress, from Zoo. to Bot.". The wife's being is eroded by putrefaction, and while he assures her that he will grieve for her, he also dismisses the value of so doing, since:

M.A. Lund ( $\square)$

University of Leicester, Leicester, UK

e-mail: maejll@leicester.ac.uk

(C) The Author(s) 2017

S. McCorristine (ed.), Interdisciplinary Perspectives on Mortality

and its Timings, Palgrave Historical Studies in the Criminal Corpse

and its Afterlife, DOI 10.1057/978-1-137-58328-4_2 
...Grieving's never

Lengthened Life

Or coaxed a single extra Breath

Out of a Body touched by Death. ${ }^{1}$

No strength of feeling will move the addressee back from "Bot." to "Zoo.", even momentarily. The facts of biological death and decay are bare and brutal. Crace's verse is an anti-elegy that seems to express mourning while dispassionately describing the physical processes of death. Yet, alongside this rather shocking viewpoint, what is notable about this poem is the way the woman is addressed: she is both informed that "You're dead" and called "Departing wife". We imagine that the wife is about to die, but the biologist is imagining her as dead already as he gives her this helpful cold comfort. There is an odd paradox in this flippant bit of verse: even while he is envisaging her as no more than "manure", there is still a sense of being attached to her (and even the botanical classification gives her some life).

This chapter looks at the speech acts that denote and surround death, and more specifically, the part they play in enacting and indicating death timings on the English Renaissance stage. According to the groundbreaking language theory propounded by J.L. Austin, speech does not only say, but also does: it performs something through the act of speaking (in his terminology, it has perlocutionary force). ${ }^{2}$ For example, when a member of the royal family says the words "I name this ship..." in the appropriate circumstances, the ship becomes named through the speaking of the words. To return to my earlier example, the phrase "You're dead" is not a merely descriptive act. It is also a performative utterance that is, moreover, heavily context-dependent. When the speaker of Crace's poem says, "You're dead", he is imagining his "departing" wife as already departed, and in a sense, is creating her as socially dead before she is biologically so. At the same time, his choice of words militates against his ruthlessly biological reading of death as simple physical decay and taxonomical change. By addressing her as dead, he allows the subject to persist, acknowledging that there is still a "you", not an "it" or even a "she". As we shall see, the tragic drama of William Shakespeare (1564-1616) has a similar fascination both with the experience of dying, and with the paradox expressed in the notion of simultaneously being, and being dead. 


\section{The Borderlands of Death: Renaissance Tragedy}

The drama of late sixteenth- and early seventeenth-century England is heavily occupied not only with deaths, but with the depiction and vocalisation of the stages around them. Most obviously, the afterlife speaks and walks on the stage in the supernatural manifestations of ghosts hungry for vengeance - a staple element of the revenge tragedy tradition. In the Shakespearean canon, Richard III, Julius Caesar, Hamlet, and Macbeth all feature revenants of some kind who communicate with the living, and even play a significant part in the plot (in the case of Julius Caesar, the title character himself returns from the dead to haunt his own play). Such memorable, and sometimes lurid, figures are not the only dramatic reflection on mortality to command attention. Thomas Kyd's (1558-1594) highly influential revenge play The Spanish Tragedy (a story framed by the narrative of a ghost seeking revenge for his murder) exploits the full dramatic potential of deaths that are not what they seem. At the climax of the tragedy, a living avenger, Hieronymo, stages his own play and invites other characters to participate. What they do not realise is that the guilty parties will be killed for real, when they naturally assume that they are only acting. It only gradually becomes apparent to the audience that the play-within-a-play has become enacted in truth: the dead characters are not going to stand up again, and the blood from their wounds is not fake. Yet they will stand up, of course, and the blood is fake, because they are actors playing characters who play characters: the fake-real-fake-real feint Kyd uses is as much a self-referential game as is the custom of boy actors playing female characters, who in turn dress up as men.

Renaissance dramatists experimented with, and challenged, the audiences' expectations and assumptions about how death occurs on stage. If we witness a character being strangled and see her immobile body lying on the stage or concealed behind a curtain, we assume that she is dead and gone, even though we know, and perhaps can even see, that the actor playing her is still breathing. As we shall later see, Shakespeare uses various conventions to indicate death, in particular verbal cues. Yet conventions can also be overturned, to complicate our notions of death timings. In some cases, the audience is privy to the secret that a character is not dead despite seeming to be so, a knowledge kept from other characters on stage. For example, in Romeo and Juliet we witness Friar Laurence explaining to Juliet his plan to reunite her with her exiled lover Romeo: she should drink a potion to suppress her physical responses, so 
that "No warmth, no breath shall testify thou livest"; each part of her body "Shall, stiff and stark and cold, appear like death" (Romeo and Juliet, 3.5.98, 103). ${ }^{3}$ When the unknowing Romeo breaks open her tomb, we know that he has misread the signs given by her body, and when he poisons himself-“Thus with a kiss I die!" (5.3.120)—we are acutely aware of the horrendous nature of this tragedy; Juliet will soon rise up from her drugged sleep-as-death to find the still-warm corpse of her new husband Romeo, and she will herself commit suicide.

Juliet's second death by stabbing is genuine and observed as such (the watchman pronounces her "bleeding, warm, and newly dead,/ Who here hath lain this two days" (5.3. 174-175)), but not all women in Shakespeare's tragedies pass away so swiftly or evidently. A strange contrast to Juliet's case is that of Desdemona, smothered by her husband Othello in a jealous rage. In such a death, there are no immediately readable signs like Juliet's fresh blood, especially since, as Othello himself has observed earlier, Desdemona has "whiter skin $[\ldots]$ than snow,/And smooth as monumental alabaster" (Othello, 5.2.4-5). Even when she is alive and in good health, Othello imagines her as a dead figure like that on a stone tomb, perhaps to lessen his guilt for what he is about to do. Her physical self presents a dramatic contrast to Juliet, in whom, even when she is drugged and seemingly "dead" within a vault, Romeo notices that "Beauty's ensign yet/Is crimson in thy lips and in thy cheeks" (Romeo and Juliet, 5.3. 94-95). When Othello first smothers Desdemona, he does not fully succeed, and remarks as much-"Not dead? Not yet quite dead?" (Othello, 5.2.95) — continuing until he can pronounce firmly that "She's dead" (5.2.100). But shortly afterwards, we discover that we cannot trust his reading of the external signs of mortality, when we hear her voice from behind the bed-curtains: "O , falsely, falsely murdered!” (5.2.126). Although we may initially conclude that she is a ghost, we soon realize that she has indeed revived, just for long enough to proclaim her innocence, and also to exonerate, rather than accuse, her husband. Her maid, Emilia, asks her "who hath done this deed?"; Desdemona's final words are "Nobody, I myself" (5.2.132, 134).

Othello is not the only example in Renaissance drama where a suffocated woman temporarily revives. Shakespeare's Jacobean contemporary John Webster (1580-1634) takes the idea even further: when the eponymous heroine of his play The Duchess of Malfi is strangled on the orders of her brother, she revives over a hundred lines after she has seemingly 
"died". The man who has carried out the murder, Bosola, realises that "She's warm, she breathes", "her eye opes", and he tells her that her husband is still alive, allowing her to die happily: "Mercy" is her final word. ${ }^{4}$ This revivification of women may, as Kaara Peterson convincingly argues, be connected to the early modern medical understanding of the female disorder hysterica passio, in which women "display the symptoms that mimic death", a representation reflecting a wider cultural anxiety that "women's bodies cannot be trusted to reflect their most fundamental status as living beings". 5 Perhaps Renaissance audiences were more sceptical about whether a female character's death was definitive unless clear signs were exhibited. Moreover, such a medical understanding allows, and even enables, the fantasy that grief can coax a single extra breath out of a body touched by death; a particular preoccupation of Shakespeare's late drama. In his play Pericles, a coffin washed up on the shore is opened to reveal a still-pink body of Thaisa, buried at sea, who is revived back into life by a skilful doctor, and at last reunited with her husband; in The Winter's Tale, there is another pink female form-the statue of the wronged late Queen Hermione - that miraculously steps off its plinth and reveals itself to be a breathing woman. The borderlands of death allow redemption as well as consolation.

\section{Becoming Dead in Shakespeare}

Renaissance drama reminds us that the boundaries between life and death can be paper-thin, that observed signs may not be sufficient, and that characters and actors inhabit worlds of being and not-being. The most striking reminder of death as merely performance is the jig at the end of a play, a traditional coda to the action. There may be a pile of bodies, or a funeral procession, but in a Renaissance tragedy that is not "it. Adieu. Farewell". As the play's action ends, the actors re-enter to dance, an experience recounted by the Swiss traveller Thomas Platter, who visited London in 1599: "On the 21 st of September, after dinner, at about two o'clock, I went with my party across the water; in the strawthatched house we saw the tragedy of the first Emperor Julius Caesar, very pleasingly performed, with approximately fifteen characters; at the end of the play they danced together admirably and exceedingly gracefully, according to their custom, two in each group dressed in men's and two in women's apparel". ${ }^{6}$ There is something of the danse macabre to this idea of reanimated corpses, but the revival of this tradition in the 
Globe Theatre in recent years demonstrates how dancing provides a sense of release for actors and audience, an emotional and aesthetic complement to the catharsis of watching tragedy.

The question "when is death?" finds a particularly nuanced response in two of Shakespeare's plays: Hamlet and King Lear. Both tragedies are invested not only in death, but in the process of becoming dead, and do so through their male protagonists. I have suggested that the phrase "You're dead" seems paradoxical, and we hear an equivalent one on the Renaissance stage:

Hamlet, thou art slain.

No med'cine in the world can do thee good.

In thee there is not half an hour of life;

(Hamlet, 5.2.266-268)

The words are spoken by Laertes, who has killed Hamlet in revenge for the murder of his father, Polonius, and the death of his sister, Ophelia. Having challenged Hamlet to a duel, Laertes poisons the tip of his foil so that even a flesh wound will kill his rival; during a scuffle in the swordplay, the foils are accidentally switched, and both men are wounded and fatally poisoned. Laertes is able to say, "thou art slain" not only because he has administered the poison, but also because he too is on the verge of death: "Lo, here I lie,/Never to rise again" (5.2.271-272), he says. His own internal feeling of approaching death becomes projected onto Hamlet, while Hamlet can see his own death in Laertes. Laertes becomes a living emblem of the traditional tomb inscription, "Eris quod sum" ("what I am, you will be").

Hamlet's recognition of what Laertes has told him reveals itself in a phrase even more paradoxical than "thou art slain": "I am dead" $(5.2 .285,290)$. Hamlet says the phrase twice within a single speech to his friend Horatio, just after they have witnessed Laertes dying. At first, we might think that Hamlet is indulging in a touch of melodrama by repeatedly drawing attention to his own process of dying. Certainly, his death is among the most protracted in the Shakespearean canon: he dies 60 lines after he has been wounded, which is twice as long as it takes Laertes to die from the same poison. As is often the case on the Renaissance stage, theatrical demands and medical theory meld in the behaviour of characters' bodies. Hamlet dies more slowly than Laertes 
because he is the protagonist, and his death should take centre stage, but also because of his physiology. According to the prevailing Galenic medical understanding of the body in this period, those people with a hot or dry (sanguine or choleric) temperament were believed to be more susceptible to the workings of poison, because the natural heat in their bodies made the poison work faster, and because they were believed to have wider arteries. ${ }^{7}$ As the preacher John Donne would later put it, "Poyson works apace upon cholerike complexions". ${ }^{8}$ The hot-headed Laertes dies before the melancholic Hamlet, whose cold humoral temperament preserves him longer, just as the dramatist allows him the prolonged time to give his "dying voice" (5.2.340), being acutely aware of his own theatricality in front of the "audience to this act" (5.2.320).

What does Hamlet mean when he says "I am dead"? Perhaps it is just another way to say, "I am dying"; "I'm as good as dead"; or "I'm done for". But this phrase is hardly colloquial. In a search across English writing of the same period, instances when someone says, "I am dead" (usually in drama) are typically preceded by "when", or "imagine", words that make clear that the speaker is predicting or imagining, not inhabiting death as Hamlet does. ${ }^{9}$ Hamlet's phrase appears to be unique on the English stage. I would argue that the mirroring of Laertes' phrase is more than simply a substitute for saying that he is dying. Hamlet, the student, is well versed in ontology, and has already revealed his reflections on what it is like to be dead, "not to be":

...To die, to sleep.

To sleep, perchance to dream. Ay, there's the rub,

For in that sleep of death what dreams may come

When we have shuffled off this mortal coil

Must give us pause. (3.1.66-70)

Hamlet has spent most of the play's action thinking about and preparing himself, firstly, to revenge the murder of his father by his uncle, King Claudius, and secondly to die. Within 10 lines he has finally achieved both: he has at long last successfully taken on the role of avenger, killing Claudius (who, incidentally, takes a mere five lines to die) with a combination of poisoned implements, and he has also become the revenged: he has taken on the status of being dead, while he is still conscious. 
There are further dimensions to Hamlet's extraordinary speech act "I am dead". The editors of the Arden edition of Hamlet note of these lines that "If Hamlet is already 'dead' when he kills the King, this may be Shakespeare's solution to the moral dilemma of the blood-guilt of the successful revenger". ${ }^{10}$ I think this explanation fails to account for Hamlet's own deep investment in the theology and ethics of revenge; for Hamlet to absolve himself of guilt through this speech act seems a solution too neat and untroubled for him. Hamlet's expression of simultaneously being, and being dead, is perhaps better understood as an articulation of death being experienced in different timings, rather than as a single event. From a legal and medical (if not an ethical) perspective, he may see himself already as a dead man. When Hamlet hurts the king with his poisoned foil, there is a general cry of "Treason, treason!" (5.2.275). Hamlet has not been tried for treason, but he has fully taken on the responsibility for killing a king, and there is hence a legal sense in which Hamlet is already dead: those who are condemned for treason (not necessarily through trial) lose all their civil rights and capacities, and forfeit their estates and their ability to transmit property to descendents. " Hamlet himself characterizes death as "this fell sergeant" who is "strict in his arrest" (5.2.288-289), exploiting the idea of himself as a prisoner. Furthermore, a medical symptom may overlay his legal and philosophical awareness. He tells Horatio that "the potent poison quite o'ercrows my spirit" (5.2.305), an expression of the moment of death as it is being experienced. The words "I am dead" may be a manifestation of that, of the symptom angor animi: that is, "the sense of being in the act of dying, differing from the fear of death or the desire of death" encountered, for example, in angina patients. ${ }^{12}$ "Angor animi" might be translated as "anguish of the spirit", and in Shakespeare's time, the term referred to mental anguish and melancholy, of the kind to which Hamlet was well-accustomed. Here, I suspect, he is also experiencing that more modern sense of the term: feeling death rather than just contemplating it.

\section{Textual Deaths in Hamlet}

If we re-pose the question "when is death?" in Hamlet, we should look further at the protagonist's final words. There is no ambiguity about his passing moment in the way that there is about Desdemona, or the 
Duchess of Malfi-no trick where an extra breath is coaxed out of him after he seems to have breathed his last. There is, however, an interesting textual variation that serves to highlight the ways in which death can be signalled, both on stage and in a reading of the printed text. Hamlet experiences death in three different ways, according to which version of the play is consulted. The first time that Hamlet appeared in print, in 1603 (the First or so-called "bad" Quarto), was in a version significantly shorter and markedly different from later editions; possibly it was a reconstruction of Shakespeare's play from memory by an actor or audience member, a "bootleg" edition with some notably garbled passages. ${ }^{13}$ In this version, Hamlet's words are (to us) unfamiliar, but conventionally final:

What tongue should tell the story of our deaths,

If not from thee? O my heart sinckes Horatio,

Mine eyes have lost their sight, my tongue his use:

Farewel Horatio, heaven receive my soule.

Ham. dies. ${ }^{14}$

Hamlet asks his friend Horatio not to commit suicide and accompany him in death, but instead to remain alive and bear testimony to what has happened. As the poison takes effect, the First Quarto Hamlet acts as a kind of witness to the physical symptoms of dying he is experiencing. The sinking heart and loss of senses are conventional medical indicators that death is near: one manual lists "difficultie of breathynge, dimnesse of sight, dulness of sense" among the warning signs. ${ }^{15}$ His articulation of physical experiences and symptoms as a representation of an unobservable, interior state is also a dramatic convention, being characteristic of the Senecan mode to which Elizabethan tragic theatre was indebted. ${ }^{16}$ But it is a firmly Christianized Senecanism, as Hamlet's final words indicate in the form of a spiritual piety, "heaven receive my soul". The stage direction confirms the obvious: "Ham. dies". The First Quarto, then, gives a triple set of indications of the moment of death: in verbalized medical symptoms, in spiritual preparation, and in an instruction to the actors (and, by extension, to the reader of the printed text).

Yet, this version is mostly rejected by editors; in the Second Quarto of 1604, he dies quite differently, or indeed, not at all (textually, at least). He starts to give a message for the Norwegian prince Fortinbras 
(whom Hamlet would like to take over the rule of Denmark), but he stops halfway through his sentence: "So tell him, with th'occurrants more and lesse/Which have solicited, the rest is silence". ${ }^{17}$ The abrupt last phrase is unaccompanied by any stage direction, and it is his friend Horatio's words in response that make clear that he has died: "Now cracks a noble hart, good night sweete Prince,/And flights of Angels sing thee to thy rest". In the First Folio, the collection of plays published 7 years after Shakespeare's death, Hamlet's last lines are nearly identical, but the text gives him a death groan " $\mathrm{O}, \mathrm{o}, \mathrm{O}, \mathrm{O}$ " and a stage direction: "Dyes". ${ }^{18}$

Although the versions are different, Hamlet's ending is unambiguous. There is no indication that he lingers on after his final line. Indeed, between the three editions we can observe a combination of methods by which death is indicated at a textual level in an English Renaissance play. The clearest is the stage direction: "Dyes". This, like all stage directions, is used sporadically in printed texts; it is altogether common to find no such stage direction, which means that the modern editor of a play usually puts one in (and sometimes has to make an educated guess about where it occurs). A death groan in a printed text ("O, $\mathrm{O}, \mathrm{O}, \mathrm{O}$ ") must be a shorthand for the combination of unscripted sound and gesture with which tragic actors such as Richard Burbage performed their death throes. It is worth remembering that the sightlines of public playhouses, with a raised stage and standing spectators in the yard, make different demands of a performed death from those in modern theatres; although the traveller Thomas Platter praised the layout of English playhouses where "everyone can well see everything", ${ }^{19}$ an actor lying down on the stage would need to die vocally as well as visually, in order to communicate to those standing round the stage. A resounding final line is another clear way of doing this. A rhyming couplet is a traditional way to end a long speech in blank verse, and is also commonly used to end a character's life. Brutus in Julius Caesar meets a self-determined death by stabbing - the "Roman way" of suicide - with a similarly self-determined couplet, and Othello does exactly the same (stabbing is generally a quick death in Shakespeare, and characters tend to die within two lines, with the exception of Antony in Antony and Cleopatra, who bungles his suicide and takes a horribly protracted hundred lines to die, split over two scenes). And the last indicator of death (although the least reliable) is a pronouncement by another character. This is often, though, where ambiguity can creep in. 


\section{Produce the Bodies: King LeAR}

I will finally turn to King Lear, another of Shakespeare's tragedies where the promised end is textually, medically, legally hard to pinpoint. When the aged and mentally frail Lear enters the stage for the last time, it is to the shock of anyone who knows only the historical source of the play. In the English chronicle histories which Shakespeare drew on as a source, the ancient English king Leir is outlived by his youngest daughter Cordeil. But in Shakespeare's version, Lear comes in carrying her seemingly lifeless body: "Howl, howl, howl [...] she's gone for ever" (King Lear, 5.3.255, 257). He declares authoritatively that "I know when one is dead, and when one lives,/She'd dead as earth", yet even so, he immediately demands the materials for testing life, a mirror and a feather, and claims that "This feather stirs, she lives" (5.3.263). In most productions, and indeed in many editions of the play, the possibility that Cordelia is still alive is rejected, and Lear's behaviour is taken as a poignant exhibition of grief and delusion. ${ }^{20}$ Yet the possibility is still hinted at, and once again the play-text supports this ambiguity. Even more than in Hamlet, there are significant variations between versions - in this case the First Quarto (1608) and the First Folio (1623) - but both have the same stage direction: "Enter Lear with Cordelia in his armes", not "with the body of Cordelia". ${ }^{21}$ This phrasing is particularly telling since, a little earlier, Lear's other daughters, one poisoned, the other stabbed, are carried on, and the stage direction specifies that "The bodies of Gonerill and Regan are brought in". The stage directions thus appear to distinguish between the representations of two who are obviously corpses, and one who may or may not be. Lear's pain is all the more prolonged if signs of Cordelia's life appear and recede, a reminder that biological death is by no means instantaneous. Shakespeare fills the stage with bodies-unusually, even those who have died offstage are brought in-so that, by the end, the royal father and the three daughters for whom he divided his kingdom are all seen lying together and carried out in the final ritual of tragedy; the First Folio even specifies the musical accompaniment: "Exeunt with a dead march". ${ }^{22}$

I have suggested that Cordelia's death timing is ambiguous where that of her sisters Goneril and Regan is not-they are identified as "bodies"-but the latter case is worthy of further scrutiny. The last scene of King Lear, like the character Hamlet, shows a preoccupation with the 
liminal state of being both alive and dead, one which all of the Lear family occupy at some point. Early on in the scene, Goneril's husband Albany takes charge of the court, as the full wickedness of a plot involving the two sisters Goneril, Regan, and their lover Edmund is revealed. Albany directly charges Edmund, as well as his own wife Goneril: "I arrest thee/On capital treason, and in thine attaint/This gilded serpent" (5.3.83-85). Attaint or attainder signifies "the legal consequences of being condemned for treason, i.e., death and forfeiture of wealth and honour, as if the blood were [...] irretrievably stained". ${ }^{23}$ Edmund, having been attainted for "heinous, manifest and many treasons" (5.3.93), is ordered to a trial by combat, which he loses, but Goneril quibbles with the legality of this. When Albany confronts her with the paper evidence of her infidelity, she responds that "the laws are mine, not thine./ Who can arraign me for't?" (5.3.156-157). Albany has married into her power and lands, and she is moreover a queen and, in her eyes, above the law.

The conflict between Albany and Goneril thus becomes a struggle over different assertions of legal authority, and, by extension, over the control of life and death. By pronouncing an attainder on Edmund and Goneril, Albany is staking a claim for his power to pronounce them both legally dead, before they are biologically extinct. When Goneril later poisons her sister and stabs herself, Albany orders attendants to "Produce the bodies, be they alive or dead" (5.3.229). Albany's careful wording reasserts the authority that Goneril has disputed: the sisters take on the status of "bodies" through habeas corpus, and also as people attainted of high treason. The equivalent is "bring up the bodies", as used in the novel of the same name by Hilary Mantel (2012), a reference to an order to bring Anne Boleyn's supposed lovers to court; the same language was used in the trials for high treason of Henry, Duke of Suffolk in 1554 and Patrick O'Collun in $1594 .^{24}$ Goneril and Regan are in all senses dead when they are brought in, and problems of jurisdiction have been sidestepped; for Albany, it is "This judgement of the heavens that makes us tremble" (5.3.230).

Ideas of medical and legal forms of death are thus raised through the demise of Lear's three daughters, but at last it is Lear's own death that shows us the full tragic force of the "when is death?" question. As Emily R. Wilson puts it, "[t]he exact moment of his passing is obscure: 
the other characters on stage seem puzzled about when Lear dies and wary of saying prematurely that ' $\mathrm{He}$ is gone indeed'. Lear has already experienced practical death so many times that the moment of his physical death seems unimportant". Lear is, in Wilson's words, an example of "tragic overliving". ${ }^{25}$ In the First Quarto, he gives a dying groan ("O, o, o, o") and gives an envoi to a world of pain in his last words, "Breake hart, I prethe breake"; there is no stage direction to mark the precise timing of his death. ${ }^{26}$ In the later First Folio, there is a clear stage direction " $\mathrm{He}$ di $[e] s ", 27$ but this revised text also erases the other formal signs of dying in Lear's own speech, and the line "Breake heart, I prythee breake" becomes an expression not of a dying moment, but of pain and grief spoken by another character who witnesses Lear's death. Lear, indeed, is looking at his dead daughter's lips, "Looke there, looke there", when the stage direction indicates that he dies-fading away, perhaps in hope that there is a sign of life.

Shakespeare's tragic drama is deeply invested in the question of how death timings occur, and in the issues of power that surround them: medically, legally, philosophically, and emotionally. Because they are performed, moments of passing become a participatory process in which the character (or actor-as-character), other characters on stage, and the audience play a role in enacting them. The words spoken by the witnesses to King Lear's death, "O let him pass" and "he is gone indeed" (5.3.312, 314 ), do not only recognise the stages of death, but also enjoin audience members or readers to let Lear pass - perhaps in a way akin to Prospero's epilogue to The Tempest, when he asks the audience to "release me from my bands/With the help of your good hands" (Epilogue, 9-10). For the process of becoming dead in a tragedy extends beyond the final lines, into the solemn music of the funeral march, the procession that carries the bodies off stage, and finally the actors' re-entry, revived, for the jig and the audience's applause. The medical and legal dimensions of becoming dead, Hamlet's testimony of death as it is being experienced, and Lear's fading moments all connect us to that communal experience of seeing and feeling staged death-part of the Aristotelian understanding of cathartic tragic drama. ${ }^{28}$ The statement to which tragedy always gestures, in the paradoxically pleasurable way that drama does, is not "you're dead" or "I am dead", but "we are dead". 


\section{Notes}

1. Jim Crace, Being Dead (London, 1999), n.p.

2. See J.L. Austin, How to Do Thing with Words: The William James Lectures Delivered at Harvard University in 1955 (Oxford, 1962).

3. References to Shakespeare's plays are included in-text. Romeo and Juliet, Othello, Hamlet, and The Tempest are referenced from William Shakespeare, The Complete Works, Stanley Wells et al. eds. (Oxford, 1988); King Lear is referenced from William Shakespeare, King Lear, R. A. Foakes ed. (London, 2003).

4. The Duchess of Malfi, 4.2.341, 345, 351 in John Webster, Three Plays D.C. Gunby ed., Rev ed. (Harmondsworth, 1995).

5. Kaara L. Peterson, Popular Medicine, Hysterical Disease, and Social Controversy in Shakespeare's England (Farnham, 2010), p. 72.

6. Ernest Schanzer, "Thomas Platter's Observations on the Elizabethan Stage", Notes and Queries, 201 (1956), p. 466.

7. Ambroise Paré, The Workes of [...] Ambrose Parey (London, 1634), sig. $3 \mathrm{~T} 5^{\mathrm{r}}$.

8. John Donne, The Oxford Edition of the Sermons of John Donne, Vol. 12: Sermons Preached at St Paul's Cathedral, 1626, Mary Ann Lund ed (Oxford, 2017), p. 28.

9. Search conducted via Early English Books Online, accessed I March 2016, http://eebo.chadwyck.com.

10. William Shakespeare, Hamlet, Ann Thompson and Neil Taylor eds. (London, 2006), p. 457.

11. See John Bellamy, The Tudor Law of Treason (London, 1979).

12. Henry Marsh, Do No Harm: Stories of Life, Death and Brain Surgery (London, 2014), p. 74.

13. See Shakespeare, Hamlet, pp. 74-86.

14. William Shakespeare, The Tragicall Historie of Hamlet Prince of Denmarke (London, 1603), sig. I3 ${ }^{\mathrm{v}}$.

15. Christopher Langton, A Very Brefe Treatise, Ordrely Declaring the Pri[n] cipal Partes of Phisick (London, 1547), sig. k5".

16. See further Gordon Braden, Renaissance Tragedy and the Senecan Tradition: Anger's Privilege (New Haven, 1985); Robert S. Miola, Shakespeare and Classical Tragedy: The Influence of Seneca (Oxford, 1992).

17. William Shakespeare, The Tragicall Historie of Hamlet, Prince of Denmarke (London, 1604), sig. G1 ${ }^{\mathrm{v}}$.

18. William Shakespeare, Mr. William Shakespeares Comedies, Histories, \& Tragedies Published According to the True Originall Copies (London, 1623), sig. $2 \mathrm{ql}^{\mathrm{r}}$. 
19. Schanzer, "Thomas Platter's Observations", p. 466.

20. Shakespeare, King Lear, p. 385, n. 254.1.

21. William Shakespeare, M. William Shak-speare: His True Chronicle Historie of the Life and Death of King Lear (London, 1608), sig. L3'; Shakespeare, Mr. William Shakespeares Comedies, sig. 2s2v.

22. Shakespeare, Mr. William Shakespeares Comedies, sig. 2s $3^{\mathrm{r}}$.

23. Shakespeare, King Lear, p. 371, n. 84.

24. House of Commons, Fourth Report of the Deputy Keeper of the Public Records (London, 1843), pp. 245, 284.

25. Emily R. Wilson, Mocked with Death: Tragic Overliving from Sophocles to Milton (Baltimore, 2004), p. 126.

26. Shakespeare, M. William Shakespeare, sig. L4 ${ }^{\mathrm{r}}$.

27. Shakespeare, $M r$. William Shakespeares Comedies, sig. $2 \mathrm{~s} 3^{\mathrm{r}}$.

28. See Aristotle, The Poetics of Aristotle: Translation and Commentary, Stephen Halliwell trans. (London, 1987).

\section{Author Biography}

Mary Ann Lund is Lecturer in Renaissance English Literature at the University of Leicester. She is the author of Melancholy, Medicine and Religion in Early Modern England: Reading 'The Anatomy of Melancholy' (Cambridge University Press, 2010), and editor of volumes 12 and 13 of The Oxford Edition of the Sermons of John Donne.

Open Access This chapter is licensed under the terms of the Creative Commons Attribution 4.0 International License (http://creativecommons.org/licenses/ by $/ 4.0 /)$, which permits use, sharing, adaptation, distribution and reproduction in any medium or format, as long as you give appropriate credit to the original author(s) and the source, provide a link to the Creative Commons license and indicate if changes were made.

The images or other third party material in this chapter are included in the chapter's Creative Commons license, unless indicated otherwise in a credit line to the material. If material is not included in the chapter's Creative Commons license and your intended use is not permitted by statutory regulation or exceeds the permitted use, you will need to obtain permission directly from the copyright holder.

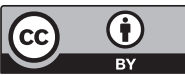

